\title{
25-Hydroxy vitamin-D, obesity, and associated variables as predictors of breast cancer risk and tamoxifen benefit in NSABP-P1
}

\author{
Eitan Amir - Reena S. Cecchini - Patricia A. Ganz • \\ Joseph P. Costantino $\cdot$ Samantha Beddows • \\ Nicola Hood • Pamela J. Goodwin
}

Received: 24 February 2012/ Accepted: 27 February 2012/Published online: 14 March 2012

(C) Springer Science+Business Media, LLC. 2012

\begin{abstract}
Observational studies suggest that host factors are associated with breast cancer risk. The influence of obesity, vitamin-D status, insulin resistance, inflammation, and elevated adipocytokines in women at high risk of breast cancer is unknown. The NSABP-P1 trial population was used for a nested case-control study. Cases were drawn from those who developed invasive breast cancer and controls selected from unaffected participants $(\leq 4$ per case) matched for age, race, 5 year Gail score, and geographic location of clinical center as a surrogate for latitude. Fasting serum banked at trial enrolment was assayed
\end{abstract}

Electronic supplementary material The online version of this article (doi:10.1007/s10549-012-2012-x) contains supplementary material, which is available to authorized users.

E. Amir · P. J. Goodwin

Division of Medical Oncology and Hematology,

Princess Margaret Hospital and University of Toronto,

Toronto, ON, Canada

R. S. Cecchini · J. P. Costantino

Biostatistical Center, National Surgical Adjuvant Breast

and Bowel Project, Pittsburgh, PA, USA

P. A. Ganz

Los Angeles Schools of Medicine and Public Health, Jonsson Comprehensive Cancer Center, University of California, Los Angeles, CA, USA

J. P. Costantino

Department of Biostatistics, University of Pittsburgh Graduate

School of Public Health, Pittsburgh, PA, USA

S. Beddows $\cdot$ N. Hood · P. J. Goodwin $(\bowtie)$

Department of Medicine, Mount Sinai Hospital and University

of Toronto, 1284-600 University Ave, Toronto,

ON M5G 1X5, Canada

e-mail: pgoodwin@mtsinai.on.ca for 25-hydroxy vitamin-D (25OHD), insulin, leptin (adipocytokine), and C-reactive protein (CRP, marker of inflammation). Logistic regression was used to test for associations between study variables and the risk of invasive breast cancer. Two hundred and thirty-one cases were matched with 856 controls. Mean age was 54, and $49 \%$ were premenopausal. There were negative correlations for 25OHD with body mass index (BMI), insulin, CRP, and leptin. BMI $\geq 25 \mathrm{~kg} / \mathrm{m}^{2}$ was associated with higher breast cancer risk (odds ratio [OR] 1.45, $p=0.02$ ) and tamoxifen treatment was associated with lower risk $(\mathrm{OR}=0.44$, $p<0.001)$. Suboptimal 25OHD $(<72 \mathrm{nmol} / \mathrm{l})$ did not influence breast cancer risk ( $\mathrm{OR}=1.06, p=0.76)$. When evaluated as continuous variables, $25 \mathrm{OHD}$, insulin, CRP, and leptin levels were not associated with breast cancer risk (all $p>0.34$ ). In this high risk population, higher BMI was associated with a greater breast cancer risk. Serum levels of 25OHD, insulin, CRP, and leptin were not independent predictors of either breast cancer risk or tamoxifen benefit.

Keywords Breast cancer - Vitamin-D · Obesity · Cancer prevention - Tamoxifen

\section{Introduction}

Numerous risk factors for the development of breast cancer have been identified and quantified [4]. However, up to $60 \%$ of breast cancers arise in the absence of known risk factors [35]. Furthermore, established risk factors do not always account for all the attributable risk [4]. Therefore, there is a need to identify and validate new risk factors in women, regardless of the presence of recognized risk factors. Women could then be better advised on their individual risk and the need for risk-reducing strategies. 
A considerable body of literature has examined the inverse association between blood levels of vitamin-D and overall cancer risk as well as the potential role of vitamin$D$ in cancer prevention [24, 28]. The greatest magnitude of association of breast cancer risk and vitamin-D comes from geographic studies which show higher incidence in patients residing at high latitudes [12]. Unfortunately, such studies do not provide direct evidence of an association of vitamin$\mathrm{D}$ with breast cancer risk. Other data linking lower blood levels of vitamin-D to breast cancer risk are inconsistent [41] (Table 1).

A number of other host-related factors such as obesity and diet have also been postulated as breast cancer risks
$[26,31]$. The association of obesity and the development of breast cancer in post-menopausal women is relatively strong [27]; a weaker association of central obesity with the development of breast cancer exists in pre-menopausal women [27]. The mechanisms underlying this risk remain unclear. Possible explanations are elevated estrogen levels, insulin resistance with consequential hyperinsulinemia, and higher levels of insulin-like-growth-factor (IGF) [42]. Adipose tissue may directly influence tumor growth or differentiation by secretion of adipose tissue-derived hormones called adipocytokines, including adiponectin and leptin [30].

Many risk factors for breast cancer are inter-related. For instance, obesity and vitamin-D deficiency are associated

Table 1 Studies assessing blood levels of vitamin-D metabolites and breast cancer risk

\begin{tabular}{|c|c|c|c|c|}
\hline Study & Study design & $\begin{array}{l}\text { Number of cases/ } \\
\text { controls }\end{array}$ & Comparison & $\begin{array}{l}\mathrm{OR} \text { or } \mathrm{RR} \\
p \text { value }\end{array}$ \\
\hline \multicolumn{5}{|c|}{ Blood collected before diagnosis of breast cancer } \\
\hline Bertone-Johnson [5] & $\begin{array}{l}\text { Nested case-control } \\
\text { (Nurses' health study) }\end{array}$ & $701 / 724$ & $\begin{array}{l}\text { Plasma } 25 \text {-hydroxy vitamin-D } \\
\text { Quintile } 1 \text { vs. } 5\end{array}$ & $\begin{array}{l}1.37 \\
p=0.06\end{array}$ \\
\hline Freedman [22] & $\begin{array}{l}\text { Nested case-control } \\
\text { (prostate, lung, colorectal and } \\
\text { ovarian cancer screening trial) }\end{array}$ & $1005 / 1005$ & $\begin{array}{l}\text { Serum } 25 \text {-hydroxy vitamin-D } \\
\text { Quintile } 1 \text { vs. } 5\end{array}$ & $\begin{array}{l}0.96 \\
p=0.81\end{array}$ \\
\hline Chlebowski [8] & $\begin{array}{l}\text { Nested case-control } \\
\text { (Women's health initiative) }\end{array}$ & $1067 / 1067$ & $\begin{array}{l}\text { Plasma } 25 \text {-hydroxy vitamin-D } \\
\text { Quintile } 1 \text { vs. } 5\end{array}$ & $\begin{array}{l}1.22 \\
p=0.20^{*}\end{array}$ \\
\hline McCullough [37] & $\begin{array}{l}\text { Nested case-control } \\
\text { (Cancer prevention study II) }\end{array}$ & $516 / 516$ & $\begin{array}{l}\text { Serum } 25 \text {-hydroxy vitamin-D } \\
\text { Quintile } 1 \text { vs. } 5\end{array}$ & $\begin{array}{l}0.92 \\
p=0.60^{*}\end{array}$ \\
\hline Engel [17] & $\begin{array}{l}\text { Nested case-control } \\
\text { (French E3 N cohort) }\end{array}$ & $636 / 1272$ & $\begin{array}{l}\text { Serum } 25 \text {-hydroxy vitamin-D } \\
<19.8 \text { vs. }>27 \mathrm{ng} / \mathrm{ml}\end{array}$ & $\begin{array}{l}1.37 \\
p=0.02 *\end{array}$ \\
\hline Almquist [3] & $\begin{array}{l}\text { Nested case-control } \\
\text { (Malmö diet and cancer study) }\end{array}$ & $764 / 764$ & $\begin{array}{l}\text { Serum } 25 \text {-hydroxy vitamin-D } \\
\text { Quartile } 1 \text { vs. } 4\end{array}$ & $\begin{array}{l}1.08 \\
p=0.71^{*}\end{array}$ \\
\hline Veldhuis [48] & $\begin{array}{l}\text { Cross-sectional study } \\
\text { (Osteoporosis and fracture clinic) }\end{array}$ & $56 / 829$ & $\begin{array}{l}\text { Serum } 25 \text {-hydroxy vitamin-D } \\
<50 \text { vs. } \geq 50 \mathrm{nmol} / 1\end{array}$ & $\begin{array}{l}1.43 \\
p=0.18\end{array}$ \\
\hline Eliassen [16] & $\begin{array}{l}\text { Nested case-control } \\
\text { (Nurses health study II) }\end{array}$ & $613 / 1218$ & $\begin{array}{l}\text { Serum } 25 \text {-hydroxy vitamin-D } \\
\text { Quartile } 1 \text { vs. } 4\end{array}$ & $\begin{array}{l}1.20 \\
p=0.32\end{array}$ \\
\hline \multicolumn{5}{|c|}{ Blood collected after diagnosis of breast cancer } \\
\hline Lowe [34] & $\begin{array}{l}\text { Hospital-based case-control } \\
\text { (UK) }\end{array}$ & $179 / 170$ & $\begin{array}{l}\text { Plasma } 25 \text {-hydroxy vitamin-D } \\
<50 \text { vs. }>150 \mathrm{nmol} / 1\end{array}$ & $\begin{array}{l}5.83 \\
p<0.001\end{array}$ \\
\hline Abbas [1] & $\begin{array}{l}\text { Population-based case-control } \\
\text { (Pre-menopusal women, Germany) }\end{array}$ & $289 / 595$ & $\begin{array}{l}\text { Plasma } 25 \text {-hydroxy vitamin-D } \\
<30 \mathrm{nmol} / 1 \text { vs. } \geq 60 \mathrm{nmol} / 1\end{array}$ & $\begin{array}{l}2.22 \\
p<0.001 *\end{array}$ \\
\hline Abbas [2] & $\begin{array}{l}\text { Population-based case-control } \\
\text { (Post-menopusal women, Germany) }\end{array}$ & $1394 / 1365$ & $\begin{array}{l}\text { Serum } 25 \text {-hydroxy vitamin-D } \\
<30 \text { vs. } \geq 75 \mathrm{nmol} / 1\end{array}$ & $\begin{array}{l}3.23 \\
p<0.001 *\end{array}$ \\
\hline Crew [11] & $\begin{array}{l}\text { Population-based case-control } \\
\text { (Long Island, NY) }\end{array}$ & $1026 / 1075$ & $\begin{array}{l}\text { Plasma } 25 \text {-hydroxy vitamin-D } \\
<20 \text { vs. }>40 \mathrm{ng} / \mathrm{ml}\end{array}$ & $\begin{array}{l}1.79 \\
p=0.002 *\end{array}$ \\
\hline Rejnmark [40] & $\begin{array}{l}\text { Nested case-control } \\
\text { (Denmark) }\end{array}$ & $142 / 420$ & $\begin{array}{l}\text { Serum } 25 \text {-hydroxy vitamin-D } \\
\text { Tertile } 1 \text { vs. } 3\end{array}$ & $\begin{array}{l}1.92 \\
p<0.05\end{array}$ \\
\hline Yao [51] & $\begin{array}{l}\text { Hospital-based case-control } \\
\text { (USA) }\end{array}$ & $220 / 156$ & $\begin{array}{l}\text { Serum } 25 \text {-hydroxy vitamin-D } \\
<20 \text { vs. } \geq 30 \mathrm{ng} / \mathrm{ml}\end{array}$ & $\begin{array}{l}2.70 \\
p<0.001 *\end{array}$ \\
\hline
\end{tabular}

$O R$ odds ratio, $R R$ risk ratio, $N S$ not significant

* Statistical test for trend 
with insulin resistance, inflammation, and elevated adipocytokines [25, 44, 47]. Cigarette smoking is associated with insulin resistance [21] as well as increased inflammation [23].

The primary aim of this study was to explore circulating 25-hydroxy vitamin-D, an indicator of vitamin-D status, as a predictor of breast cancer risk after adjustment for potential confounding baseline factors. Secondary aims included assessment of the relationships between obesity, 25-hydroxy vitamin-D levels, insulin resistance, C-reactive protein (CRP, a marker of inflammation), and leptin (an adipocytokine), and to evaluate whether these factors were associated with differential benefit from chemoprevention in a prospective cohort of patients enrolled in the National Surgical Adjuvant Breast and Bowel Project Protocol (NSABP) P1. We hypothesized that 25-hydroxy vitamin-D levels would be inversely related to breast cancer risk in women receiving both tamoxifen and placebo, that the effect of tamoxifen would be modified by 25-hydroxy vitamin-D levels, and that associations of 25-hydroxy vitamin-D levels with breast cancer risk would be independent of the effects of insulin, adipocytokines, and inflammatory markers.

\section{Materials and methods}

\section{Study population}

A case-control study design nested in the NSABP-P1 trial population was performed. Between 1992 and 1997, the NSABP-P1 trial randomized 13,388 women, age 35 years or older and at increased risk for breast cancer [Gail model 5 year score $\geq 1.66 \%$ or history of lobular carcinoma in situ (LCIS)] to 5 years of tamoxifen (20 mg daily) or matched placebo [19]. Prior to randomization, all participants provided fasting blood specimens which were processed into $1-\mathrm{ml}$ aliquots and frozen at $-80^{\circ} \mathrm{C}$. The trial was stopped early after a median follow-up of 54.6 months as the data-monitoring committee determined that the $49 \%$ relative reduction in risk of invasive breast cancer had met pre-specified stopping rules. At that time, treatment allocation was unblinded and placebo participants were offered tamoxifen or the opportunity to participate in a subsequent chemoprevention trial. A total of 270 participants developed invasive breast cancer before the study was unblinded.

Cases included participants who developed invasive breast cancer before unblinding, had sufficient quantity and quality of stored blood samples, and provided additional consent for the use of these materials for further research. Controls included participants who did not develop invasive or non-invasive breast cancer during the course of follow-up before unblinding and were matched for age
( \pm 5 years), 5 year Gail score $(\leq 2.24 \%, 2.25-3.48 \%$, $\geq 3.49 \%$ ), race, and participant's clinical center as a surrogate for latitude of residence. Up to four matched controls for each invasive breast cancer were selected. The study was approved by the institutional ethics boards of both Mount Sinai Toronto and NSABP.

\section{Laboratory assays}

Frozen aliquots of serum measuring $1 \mathrm{ml}$ were obtained from the NSABP biospecimen repository. Specimens were thawed and then analyzed for 25-hydroxy vitamin-D, insulin, and CRP on a single run. Testing for leptin was carried out on a separate run. 25-Hydroxy vitamin-D was assayed by the Liaison 25-hydroxy vitamin-D total assay chemiluminescent immunoassay (Diasorin Inc, Mississauga, ON, intra- and inter-assay co-efficient of variability $(\mathrm{CV})$ were $6.7 \%$ and 11.7-18.4\%, respectively). The range of detection for this platform was 10-375 nmol/l. Insulin was assayed by the Roche Diagnostics electrochemiluminescence immunoassay (Roche Diagnostics Canada Inc, Laval, QC, intra- and interassay $\mathrm{CV}$ were both $<3.7 \%$ ). This assay has an analyzable range of 1.39-6,945 pmol/l. CRP was assayed by the Roche Diagnostics particle-enhanced immunoturbidimetric assay (Roche Diagnostics Canada Inc, Laval, QC, intra and interassay CV were $1.8 \%$ and 5.2-5.7\%, respectively) which can detect levels between 0.1 and $20 \mathrm{mg} / \mathrm{l}$. Finally, leptin was measured by the Linco sandwich enzyme linked immunosorbent assay (Millipore Inc, Billerica, MA, intra- and interassay $\mathrm{CV}$ were 3.8 and $4.4 \%$, respectively). This platform had a range of detection between 0.5 and $100 \mathrm{ng} / \mathrm{ml}$.

\section{Review and meta-analysis}

In order to place the results of this study in context, our data were pooled together with other published data exploring 25-hydroxy vitamin-D and breast cancer risk. MEDLINE (Host: PubMed) was searched and a systematic review of the literature was carried out and trials reporting association between breast cancer and serum levels of 25-hydroxy vitamin-D were included. There were two preplanned cohorts for this meta-analysis: (1) studies where blood was collected after the diagnosis of breast cancer and (2) studies where blood was collected before the diagnosis of breast cancer. Odds ratios (ORs) were extracted from individual studies, weighted using the generic inverse variance approach, and pooled using the DerSimonian and Laird random-effects method [15].

Statistical analysis

Spearman's rho was used to assess the correlation of 25-hydroxy vitamin-D levels with BMI, insulin, CRP, and 
leptin levels, and to assess the correlation between 25-hydroxy vitamin-D levels and the latitude of clinical center. The magnitude of correlation was assessed as described by Burnand et al. [6]. The distribution of cases by participant and tumor characteristics was determined and differences between the distributions for those with 25-hydroxy vitamin-D levels $<72 \mathrm{nmol} / 1$ and those with levels $\geq 72 \mathrm{nmol} / 1$ were compared using the $\chi^{2}$ test. This prior selected value for optimal blood levels of 25-hydroxy vitamin-D was based on the best available data at study initiation [13, 29]. It pre-dated the Institute of Medicine report suggesting a cut-off of $50 \mathrm{nmol} / 1$ [43]. In view of the inconsistent data regarding optimal cut-offs for optimal 25-hydroxy vitamin-D levels, in initial analyses, 25-hydroxy vitamin-D levels were evaluated as a dichotomized parameter cut at $\geq 72 \mathrm{nmol} / \mathrm{l}$. Analyses were then repeated using log-transformed 25-hydroxy vitamin-D levels as a continuous variable. The association between serum 25-hydroxy vitamin-D levels and the risk of developing invasive breast cancer was evaluated using conditional logistic regression. The nature of the association was evaluated, initially in the univariable setting, and then in the multivariable setting with adjustment for potential confounding baseline factors including tamoxifen treatment, BMI, history of osteoporosis, cigarette smoking, and exogenous hormone use. Interaction between tamoxifen treatment and levels of serum markers was also assessed during multivariable modeling. The independent association with breast cancer risk was also evaluated for baseline serum levels of insulin, CRP, and leptin, all assessed as log-transformed continuous variables. When using continuous variables, ORs compared the midpoint of the upper quartile to the midpoint of the lower quartile. Statistical significance of parameters included in the regression models was assessed using the likelihood ratio test. Statistical significance of all testing was based on a two-sided test using an alpha level of 0.05 .

\section{Results}

Data were available for 231 case participants (Fig. 1). Four matched controls were obtained for 196 of the cases (84.8\%), three matched controls for 12 cases (5.2\%), two matched controls for 13 cases $(5.6 \%)$, and for ten cases (4.3\%) only one matched control was obtained. Thus, the total study population comprised 1,087 participants (231 cases and 856 matched controls). The mean age was 53.6 years (standard deviation [SD] 8.7); mean BMI was $27.2 \mathrm{~kg} / \mathrm{m}^{2}$ (SD 5.7); and mean Gail model 5 year risk was $4.08 \%$ (SD 2.72). Forty-nine percent were pre-menopausal. Demographic factors for cases and controls and tumor characteristics for cases are shown in Table 2. Other than treatment, the only factor that showed a statistically significant difference between cases and controls was BMI. The percent of participants demonstrating sufficient levels ( $\geq 72 \mathrm{nmol} / \mathrm{l}$ ) of 25 -hydroxy vitamin-D levels was $24.2 \%$ among the cases and $27.8 \%$ among the controls.

Descriptive analysis of serum variables and correlations between variables are shown in Table 3 and correlations between BMI and serum variables are shown in Fig. 2 . There was no correlation between 25-hydroxy vitamin-D levels and latitude of the participant's clinical center (rho $=-0.02 ; p=0.45)$. There were weak positive correlations between age and insulin, CRP and leptin levels, and a weak negative correlation with 25-hydroxy vitaminD. The rho for age and insulin, CRP, leptin, and 25 -hydroxy vitamin-D were $0.15,0.20,0.12$, and -0.11 , respectively (Supplementary Figure).

The results of univariable and multivariable conditional logistic regression modeling of the risk of developing invasive breast cancer when using 25-hydroxy vitamin-D as a dichotomous variable are shown in Table 4. The univariable OR for suboptimal vitamin-D status (serum 25-hydroxy vitamin-D $<72 \mathrm{nmol} / \mathrm{l}$ ) was $1.25,95 \%$ confidence intervals (CI) were $0.88-1.77,(p=0.21$; Table 4-Model 1$)$. When adjusting for tamoxifen treatment and BMI (Table 4-Model 3 ), the OR for the effect of suboptimal 25-hydroxy vitamin-D decreased to 1.06 (95\% CI $0.73-1.53, p=0.76$ ). In this model, tamoxifen treatment showed a $56 \%$ reduction in the odds of invasive breast cancer (OR $=0.44,95 \%$ CI $0.32-0.61, p<0.001)$; and the OR for BMI $\geq 25 \mathrm{~kg} / \mathrm{m}^{2}$ was 1.45 (95\% CI 1.06-2.00, $p=0.02$ ). When BMI was assessed as three discrete categories $(<25.0,25.0-29.9$, and $\geq 30.0 \mathrm{~kg} /$ $\mathrm{m}^{2}$ ) in this multivariable model, there was little change to the effect of suboptimal 25-hydroxy vitamin-D ( $\mathrm{OR}=1.07$, $p=0.73$, Table 4-Model 4).

In univariable analysis as a continuous variable, 25-hydroxy vitamin-D again did not show a statistically significant association with invasive breast cancer (OR for upper versus lower quartile $=0.77,95 \%$ CI $0.55-1.06, p=0.11$; Table 5 , first row). When assessed as a continuous variable and adjusted for treatment and BMI (Table 5, fourth from bottom row), 25-hydroxy vitamin-D, did not show a statistically significant association with invasive breast cancer (OR for upper versus lower quartile $=0.86,95 \%$ CI $0.62-1.21$, $p=0.40)$.

There was no evidence of interaction between tamoxifen treatment and any serum markers. The $p$ value for interaction between tamoxifen treatment and 25-hydroxy vitamin-D, insulin, CRP, and leptin were 0.52, 0.49, 0.83, and 0.68 , respectively.

History of osteoporosis, cigarette smoking, and exogenous hormone use (oral contraceptive pill or hormone replacement therapy) were not associated with statistically 


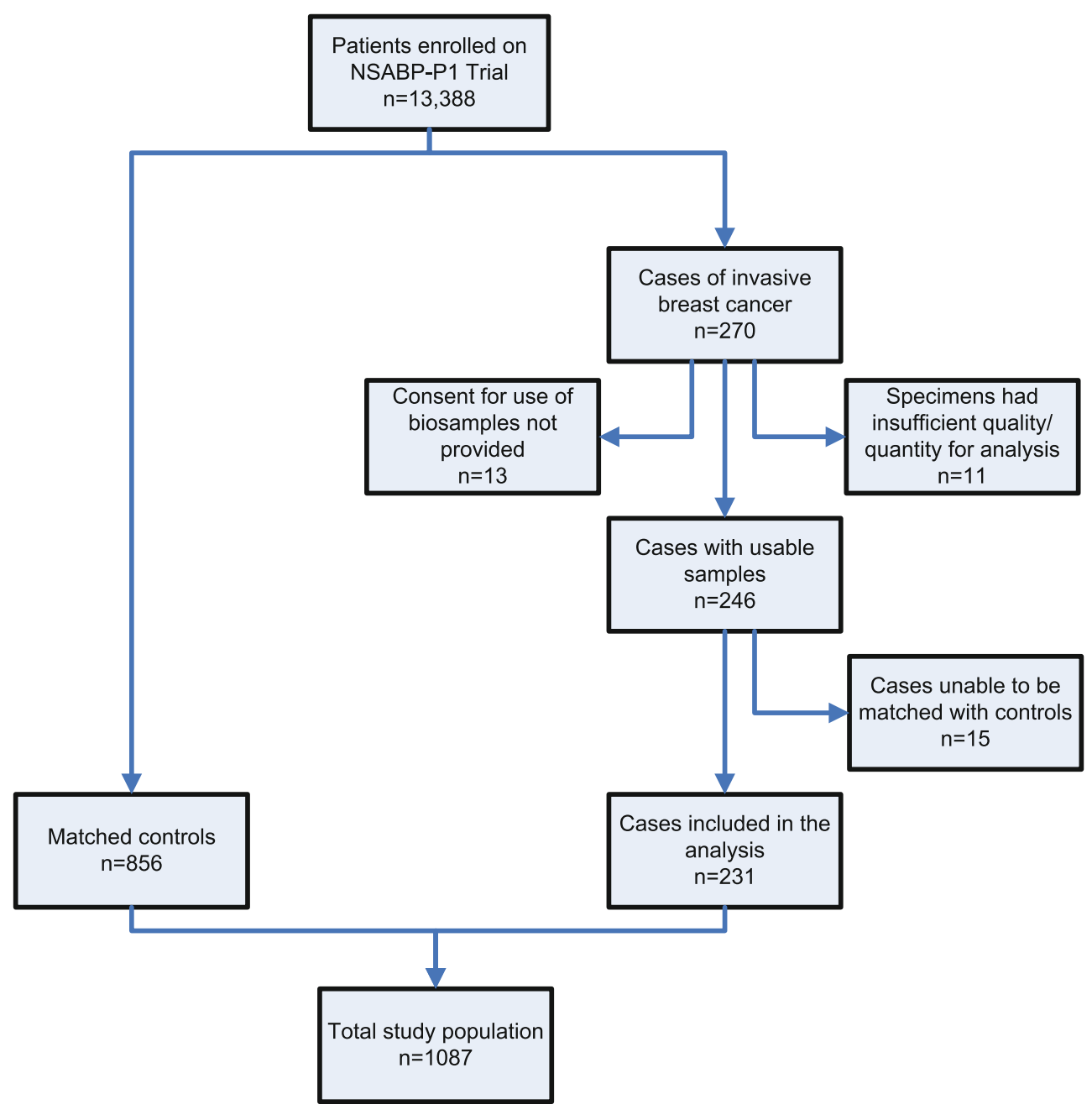

Fig. 1 CONSORT diagram

increased odds of invasive breast cancer. The univariable OR for history of osteoporosis was $1.42 \quad(95 \%$ CI $0.74-2.76, p=0.30$ ). The univariable $\mathrm{OR}$ for smoking (upper quartile [ $\geq 28$ years] versus never smoking) was 1.12 (95\% CI $0.74-1.70, p=0.35$ ), and for exogenous hormone use (ever versus never) was 0.90 (95\% CI $0.64-1.27, p=0.54$ ). History of osteoporosis, smoking, and hormone use remained non-significant when included in the multivariable model with suboptimal 25-hydroxy vitamin-D, tamoxifen treatment, and BMI ( $\geq 25.0$ vs $<25.0 \mathrm{~kg} / \mathrm{m}^{2}$ ). The OR for history of osteoporosis was 1.28 (95\% CI $0.65-2.53, p=0.48$ ), the OR for smoking for at least 28 years compared with never smoking was 1.15 (95\% CI $0.75-1.76, p=0.46$ ), and the OR for prior hormone use was 0.89 (95\% CI $0.63-1.26, p=0.51$ ).

Menopausal status did not influence breast cancer risk in either univariable or multivariable analyses (Supplementary Table). The adjusted OR for post-menopause was 0.90 (95\% CI 0.51-1.58, $p=0.70$, Supplemental Table-Model $3)$. There was also no significant interaction between BMI and menopausal status (Supplemental Table-Model 4, $p=0.32$ ).

In univariable analyses and after adjusting for tamoxifen treatment and BMI in multivariable modeling, plasma levels of insulin, CRP, and leptin did not show statistically significant effects on development of invasive breast cancer (Table 5, last three rows).

Meta-analysis of published studies assessing the association of blood levels of 25-hydroxy vitamin-D and breast cancer showed variability. In all six studies where blood levels of 25-hydroxy vitamin-D were measured after diagnosis of breast cancer, there was a significant inverse association between 25-hydroxy vitamin-D and breast cancer. Pooled data showed a highly significant OR of 2.49 (95\% CI 1.93-3.21, $p<0.001$ ). Among studies, where levels were measured before breast cancer diagnosis, only one out of nine studies showed a significant association between levels of vitamin-D metabolites and breast cancer and pooled data showed only limited association $(\mathrm{OR}=1.10,95 \% \quad$ CI $1.00-1.20, p=0.04$, Table 1 ; 
Table 2 Participant and tumor characteristics among cases and controls

Participant or tumor characteristic

Total

$\frac{\text { Cases }}{N} \quad \%$

Controls

N \%

Age (years)

$\leq 49$

$50-59$

$\geq 60$

Treatment

Placebo

Tamoxifen

5 -year predicted breast cancer risk (\%)

$$
\begin{aligned}
& \leq 2.24 \\
& 2.25-3.48 \\
& \geq 3.49
\end{aligned}
$$

Body mass index

$$
\begin{aligned}
& <25.0 \\
& \geq 25.0
\end{aligned}
$$

Smoking history (years)

None

$<18$

$18-27$

$\geq 28$

Unknown

History of hormone use

No

$$
\text { Yes }
$$

No. $1^{\circ}$ relatives with breast cancer

$$
0
$$

1

$\geq 2$

Menopausal status

\section{Premenopausal \\ Postmenopausal}

Unknown

History of breast atypical hyperplasia

$$
\text { No }
$$

Yes

History of osteoporosis

$$
\text { No }
$$

$$
\text { Yes }
$$

25-Hydroxy vitamin-D concentration

$$
\begin{aligned}
& <72 \mathrm{nmol} / \mathrm{l} \\
& \geq 72 \mathrm{nmol} / \mathrm{l}
\end{aligned}
$$

Type of invasive cancer

Infiltrating duct carcinoma

Other

470

299

318

605

482

300

293

494

444

643

592

173

143

175

4

273

814

220

605

262

530

493

64

64

986

101

1034

1034

53

793

294

17

171
60

Estrogen receptor status

Negative

Positive

Unknown

$\begin{array}{llll}96 & 41.6 & 374 & 43.7 \\ 66 & 28.6 & 233 & 27.2 \\ 69 & 29.9 & 249 & 29.1\end{array}$

$\begin{array}{llll}164 & 71.0 & 441 & 51.5\end{array}$

$<.0001$

$\begin{array}{llll}67 & 29.0 & 415 & 48.5\end{array}$

$\begin{array}{llll}64 & 27.7 & 236 & 27.6\end{array}$

0.99

$\begin{array}{llll}63 & 27.3 & 230 & 26.9\end{array}$

$\begin{array}{llll}104 & 45.0 & 390 & 45.6\end{array}$

$\begin{array}{llll}79 & 34.2 & 365 & 42.6\end{array}$

$\begin{array}{llll}152 & 65.8 & 491 & 57.4\end{array}$

\section{7}$$
50.6
$$

475

55.5

16.1

35
39

$15.2 \quad 138$

12.1

$\begin{array}{lll}16.9 & 104 & 12.1\end{array}$

39

$16.9 \quad 136$

15.9

$0.4 \quad 3$

0.4

1

60

26.0

213

24.9

0.73

171

74.0

643

75.1

$\begin{array}{llll}47 & 20.3 & 173 & 20.2\end{array}$

$\begin{array}{llll}121 & 52.4 & 484 & 56.5\end{array}$

$\begin{array}{llll}63 & 27.3 & 199 & 23.2\end{array}$

113

\section{9}

$$
\begin{aligned}
& 113 \\
& 102
\end{aligned}
$$

48.9
44.2

417

48.7

45.7$$
16
$$$$
6.9
$$

391

5.6

$$
204
$$

$$
88.3
$$

$$
782
$$

91.4

0.16

27

$11.7 \quad 74$

8.6

0.41

$\begin{array}{rrlll}216 & 93.5 & 818 & 95.6 & 0.20 \\ 15 & 6.5 & 38 & 4.4 & \end{array}$

15

$\begin{array}{lllll}175 & 75.8 & 618 & 72.2 & 0.28\end{array}$

$\begin{array}{llll}56 & 24.2 & 238 & 27.8\end{array}$

$\begin{array}{rrrr}60 & 60 & 26.0 & - \\ 56 & 56 & 24.2 & - \\ 158 & 158 & 68.4 & - \\ 17 & 17 & 7.4 & -\end{array}$


Table 2 continued

\begin{tabular}{|c|c|c|c|c|c|c|}
\hline \multirow[t]{2}{*}{ Participant or tumor characteristic } & \multirow[t]{2}{*}{ Total } & \multicolumn{2}{|c|}{ Cases } & \multicolumn{2}{|c|}{ Controls } & \multirow[t]{2}{*}{$p^{*}$} \\
\hline & & $N$ & $\%$ & $N$ & $\%$ & \\
\hline \multicolumn{7}{|l|}{ Progesterone receptor status } \\
\hline Negative & 85 & 85 & 36.8 & - & - & - \\
\hline Positive & 123 & 123 & 53.2 & - & - & \\
\hline Unknown & 23 & 23 & 10.0 & - & - & \\
\hline \multicolumn{7}{|l|}{ Presenting cancer stage } \\
\hline I & 131 & 131 & 56.7 & - & - & - \\
\hline II & 76 & 76 & 32.9 & - & - & \\
\hline III-IV & 14 & 14 & 6.1 & - & - & \\
\hline Unknown & 10 & 10 & 4.3 & - & - & \\
\hline
\end{tabular}

Table 3 Descriptive analysis of and correlations between serum variables

\begin{tabular}{|c|c|c|c|c|c|c|c|}
\hline \multirow[t]{2}{*}{ Variable } & \multirow[t]{2}{*}{ Mean } & \multirow[t]{2}{*}{ Standard deviation } & \multicolumn{5}{|c|}{ Spearman's correlation rho* } \\
\hline & & & 25-Hydroxy vitamin-D & Insulin & CRP & Leptin & BMI \\
\hline $\begin{array}{l}\text { 25-Hydroxy vitamin-D } \\
(\mathrm{nmol} / \mathrm{l})\end{array}$ & 57.9 & 25.3 & - & -0.23 & -0.15 & -0.22 & -0.22 \\
\hline $\begin{array}{l}\text { Insulin } \\
(\mathrm{pmol} / \mathrm{l})\end{array}$ & 53.4 & 50.0 & -0.23 & - & 0.44 & 0.66 & 0.58 \\
\hline $\begin{array}{l}\mathrm{CRP} \\
(\mathrm{mg} / \mathrm{l})\end{array}$ & 3.5 & 9.7 & -0.15 & 0.44 & - & 0.53 & 0.54 \\
\hline $\begin{array}{l}\text { Leptin } \\
(\mu \mathrm{mol} / 1)\end{array}$ & 29.6 & 21.7 & -0.22 & 0.66 & 0.53 & - & 0.79 \\
\hline $\begin{array}{l}\text { BMI } \\
\left(\mathrm{kg} / \mathrm{m}^{2}\right)\end{array}$ & 27.2 & 5.7 & -0.22 & 0.58 & 0.54 & 0.79 & - \\
\hline
\end{tabular}

* All correlations statistically significant at $p<0.001$

Fig. 3). There was a statistically significant difference between the two analysis subgroups $(p<0.001)$.

\section{Discussion}

Recent research has focused on the identification and validation of new risk factors predictive of breast cancer occurrence. There has been substantial interest in host factors such as obesity, vitamin-D status, adipocytokines, and inflammation and immune function. 25-Hydroxy vitamin-D concentrations have been related to factors associated with increased risk of cancer including obesity, circulating leptin levels [36], inflammatory markers [54], and insulin resistance [20]. It has been hypothesized that vitamin-D deficiency may explain increased cancer rates [33]. However, a recent report from the Institute of Medicine suggested that there are limited data supporting the association of vitamin-D status with cancer in general [43]. It remains unclear if any of the above-mentioned host factors are independent predictors of breast cancer risk.
This study, conducted in a population of women at high risk of breast cancer has shown that higher BMI was associated with increased breast cancer risk. There was a very weak, but statistically significant, negative correlation of BMI with 25-hydroxy vitamin-D and moderate to strong and significant positive correlations with insulin, CRP and leptin levels. However, when adjusting for baseline BMI, serum levels of 25-hydroxy vitamin-D, insulin, CRP and leptin were not significantly associated with breast cancer. It is unlikely that using different cut-offs for optimal 25-hydroxy vitamin-D would influence results as when assessed as a continuous variable, 25-hydroxy vitamin-D was also not seen to be associated with breast cancer risk. Of interest, there was no evidence of interaction between these factors and treatment. This suggests that these factors are not independent predictors of breast cancer risk or tamoxifen benefit in this high risk population.

The negative correlation between 25-hydroxy vitamin-D and BMI has been described previously [38], and may be explained by a volume-distribution effect with lower bioavailability of fat-soluble vitamin-D metabolites in overweight and obese individuals with excess adipose tissue [49]. 

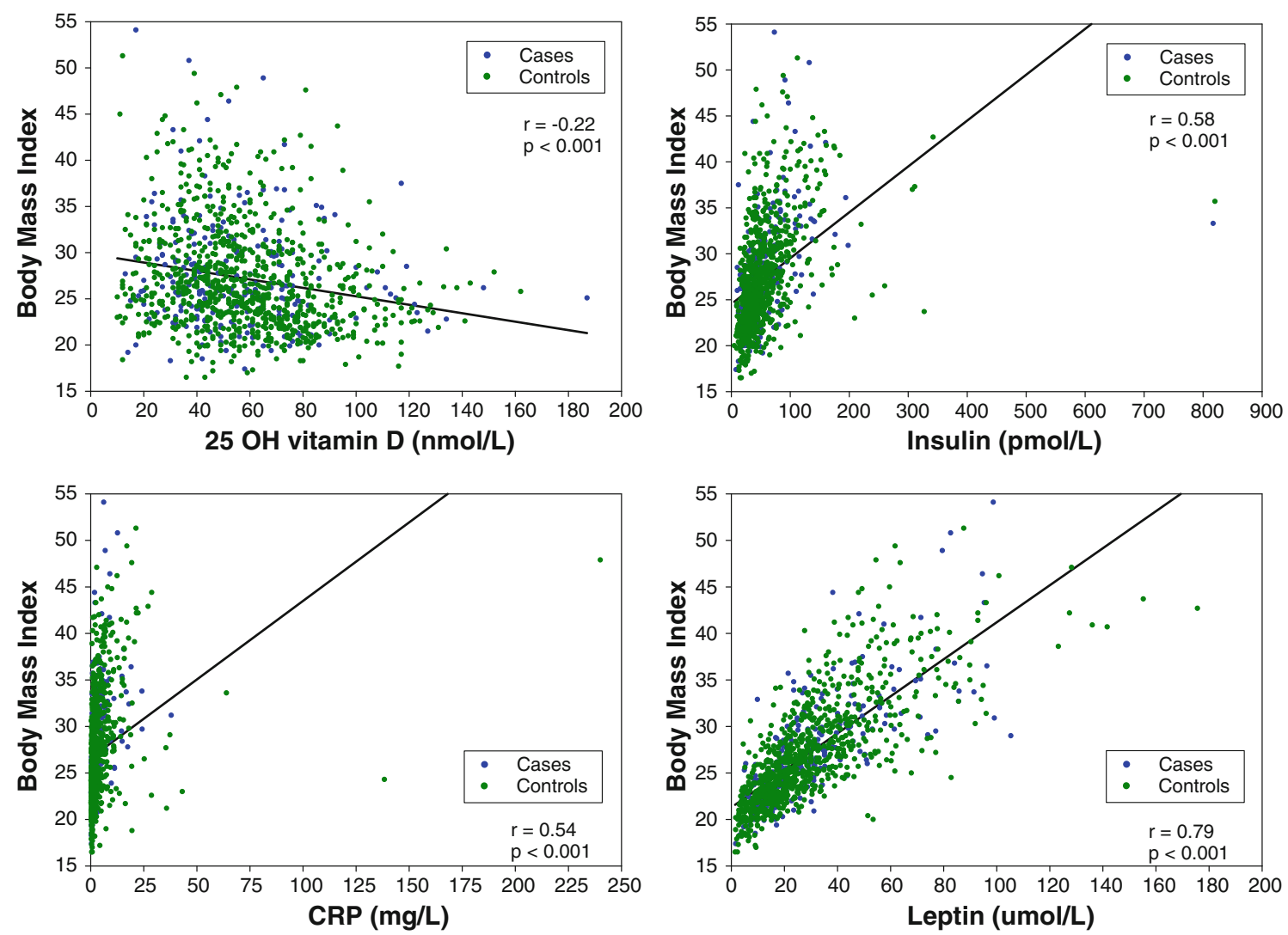

Fig. 2 Correlations between BMI and 25-hydroxy vitamin-D, insulin, CRP, and leptin

Positive correlations with insulin, leptin, and CRP have also been reported previously and may relate to the cytokine milieu associated with the metabolic syndrome [50]. No correlation was seen between 25-hydroxy vitamin-D levels and latitude of clinical center. This may be explained by the clinical center only being a rough surrogate for latitude of residence. Furthermore, no data were available on vitamin-D supplementation and this may confound this geographic analysis. However, a true absence of effect of latitude on 25-hydroxy vitamin-D levels in this population cannot be excluded.

A number of factors may explain the inconsistent association of blood levels of vitamin-D metabolites and breast cancer. First, it is possible that findings are compromised by reverse causation bias. Our meta-analysis has shown that significant association between vitamin-D metabolites and breast cancer were predominantly seen in studies where blood levels were collected after breast cancer diagnosis. This cohort was significantly different from the group where blood levels were collected before breast cancer diagnosis where only limited association between breast cancer and vitamin-D metabolite levels was seen. Similar results have been reported in other pooled analyses [7, 9, 52]. Analyses of blood drawn after breast cancer diagnosis may be prone to error as the blood parameter may be affected by the presence of breast cancer. Breast cancer cells have been shown to possess vitamin-D catalytic enzymes [18, 45] and these may interfere with standard 25-hydroxy vitamin-D assay techniques. Second, patients diagnosed with breast cancer may modify their lifestyle (such as diet, dietary supplementation, physical activity, and/or sun exposure), and this may lead to post-diagnosis changes in vitamin-D metabolite levels. Finally, the duration of follow-up for patients included in this analysis was less than 55 months. It is possible that this duration was not sufficiently long to observe the effects of blood levels of vitamin-D and cancer risk.

Prophylactic therapy with tamoxifen was protective of breast cancer with an OR of 0.44. This was consistent with the whole NSABP-P1 population suggesting balanced sampling of cases and controls. Consistent with prior data [31], higher BMI was shown to lead to increased breast cancer. Overweight and obese patients (BMI $>25 \mathrm{~kg} / \mathrm{m}^{2}$ ) had a statistically significant relative increase in the odds of breast cancer of $45 \%$. A number of mechanisms have been suggested for this association. It has been proposed that obesity is associated with insulin resistance and hyperinsulinemia [42]. Our data suggest that the level of insulin does not influence cancer risk in this high risk population, and therefore implies that other, perhaps unknown 
Table 4 Univariable and multivariable analysis of the association of 25-hydroxy vitamin-D with invasive breast cancer

\begin{tabular}{|c|c|c|c|c|}
\hline Model number & Variables in model & Odds ratio & $95 \%$ CI for odds ratio & $p$ value \\
\hline \multirow[t]{3}{*}{ Model 1} & \multicolumn{4}{|l|}{ 25-Hydroxy vitamin-D } \\
\hline & $<72 \mathrm{nmol} / 1$ & 1.25 & $0.88-1.77$ & 0.21 \\
\hline & $\geq 72 \mathrm{nmol} / \mathrm{l}$ & 1.00 & & \\
\hline \multirow[t]{6}{*}{ Model 2} & \multicolumn{4}{|l|}{ 25-Hydroxy vitamin-D } \\
\hline & $<72 \mathrm{nmol} / 1$ & 1.14 & $0.79-1.63$ & 0.48 \\
\hline & $\geq 72 \mathrm{nmol} / \mathrm{l}$ & 1.00 & & \\
\hline & \multicolumn{4}{|l|}{ Treatment } \\
\hline & Placebo & 1.00 & & \\
\hline & Tamoxifen & 0.45 & $0.33-0.61$ & $<0.001$ \\
\hline \multirow[t]{9}{*}{ Model 3} & \multicolumn{4}{|l|}{ 25-Hydroxy vitamin-D } \\
\hline & $<72 \mathrm{nmol} / 1$ & 1.06 & $0.73-1.53$ & 0.76 \\
\hline & $\geq 72 \mathrm{nmol} / \mathrm{l}$ & 1.00 & & \\
\hline & \multicolumn{4}{|l|}{ Treatment } \\
\hline & Placebo & 1.00 & & \\
\hline & Tamoxifen & 0.44 & $0.32-0.61$ & $<0.001$ \\
\hline & \multicolumn{4}{|l|}{ Body mass index } \\
\hline & $<25.0$ & 1.00 & & \\
\hline & $\geq 25.0$ & 1.45 & $1.06-2.00$ & 0.02 \\
\hline \multirow[t]{10}{*}{ Model 4} & \multicolumn{4}{|l|}{ 25-Hydroxy vitamin-D } \\
\hline & $<72 \mathrm{nmol} / 1$ & 1.07 & $0.74-1.54$ & 0.73 \\
\hline & $\geq 72 \mathrm{nmol} / 1$ & 1.00 & & \\
\hline & \multicolumn{4}{|l|}{ Treatment } \\
\hline & Placebo & 1.00 & & \\
\hline & Tamoxifen & 0.44 & $0.32-0.61$ & $<0.001$ \\
\hline & \multicolumn{4}{|l|}{ Body mass index } \\
\hline & $<25.0$ & 1.00 & & \\
\hline & $25.0-29.9$ & 1.51 & $1.06-2.15$ & \\
\hline & $\geq 30.0$ & 1.38 & $0.93-2.03$ & 0.06 \\
\hline
\end{tabular}

Table 5 Univariable and multivariable analyses of the association of log transformed plasma levels of 25-hydroxy vitamin-D, insulin, CRP, and leptin with invasive breast cancer

\begin{tabular}{|c|c|c|c|c|c|}
\hline Adjustment variables & Variable assessed & Comparison* & Odds ratio & $95 \% \mathrm{CI}$ & $p$ \\
\hline \multirow[t]{4}{*}{ None } & 25-Hydroxy vitamin-D (nmol/l) & 86 vs. 31 & 0.77 & $0.55-1.06$ & 0.11 \\
\hline & Insulin $(\mathrm{pmol} / \mathrm{l})$ & 87 vs. 22 & 1.04 & $0.76-1.44$ & 0.79 \\
\hline & $\mathrm{CRP}(\mathrm{mg} / \mathrm{l})$ & 6.5 vs. 0.4 & 1.05 & $0.85-1.30$ & 0.64 \\
\hline & Leptin $(\mu \mathrm{mol} / \mathrm{l})$ & 53.1 vs. 9.8 & 1.38 & $0.99-1.93$ & 0.052 \\
\hline \multirow[t]{4}{*}{ Treatment } & 25-Hydroxy vitamin-D (nmol/l) & 86 vs. 31 & 0.81 & $0.58-1.13$ & 0.23 \\
\hline & Insulin $(\mathrm{pmol} / \mathrm{l})$ & 87 vs. 22 & 1.03 & $0.75-1.43$ & 0.84 \\
\hline & $\mathrm{CRP}(\mathrm{mg} / \mathrm{l})$ & 6.5 vs. 0.4 & 1.07 & $0.86-1.33$ & 0.53 \\
\hline & Leptin $(\mu \mathrm{mol} / \mathrm{l})$ & 53.1 vs. 9.8 & 1.37 & $0.98-1.92$ & 0.07 \\
\hline \multirow[t]{4}{*}{ Treatment and BMI } & 25-Hydroxy vitamin-D (nmol/l) & 86 vs. 31 & 0.86 & $0.62-1.21$ & 0.40 \\
\hline & Insulin (pmol/l) & 87 vs. 22 & 0.84 & $0.58-1.21$ & 0.34 \\
\hline & $\mathrm{CRP}(\mathrm{mg} / \mathrm{l})$ & 6.5 vs. 0.4 & 0.95 & $0.75-1.21$ & 0.68 \\
\hline & Leptin $(\mu \mathrm{mol} / \mathrm{l})$ & 53.1 vs. 9.8 & 1.09 & $0.71-1.68$ & 0.70 \\
\hline
\end{tabular}

* Midpoint of the upper quartile to the midpoint of the lower quartile 
Fig. 3 Forest plot of odds ratios for breast cancer risk comparing low to high blood levels of vitamin-D metabolites. Odds ratios for each study are represented by the squares, the size of the square represents the weight of the trial in the metaanalysis, and the horizontal line crossing the square represents the $95 \%$ confidence interval. The diamonds represent the estimated pooled effect based on each cohort individually (labeled sub-total) and for all cohorts together (labeled total). Test of subgroup differences relates to the test of heterogeneity between the two subgroups as defined by Deeks et al. [14]. All $p$ values are two-sided

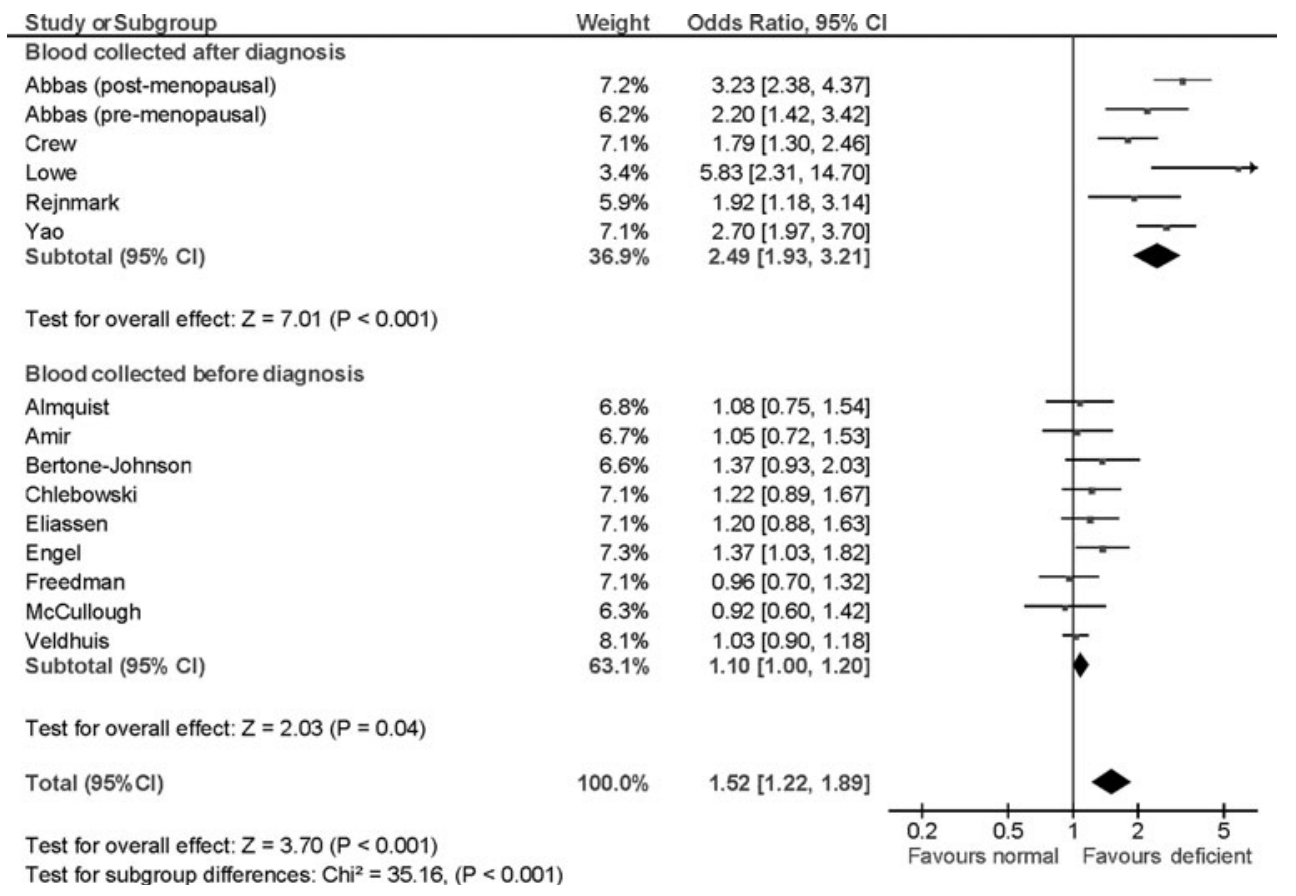

mechanisms may explain the association of BMI and breast cancer risk. The association of BMI and breast cancer has been predominantly seen in post-menopausal women, and has also been observed in pre-menopausal women with central obesity [27]. In our study, $49 \%$ of patients were premenopausal. An analysis of the interaction between BMI and menopausal status was not significant. However, as cases and controls were matched for age and this variable is highly correlated with menopausal status, it is difficult to interpret these findings accurately.

Inflammation has been associated with increased risk of breast cancer [10, 39]. CRP is a marker of systemic inflammation, but data on its association with breast cancer risk remains sparse. Our data showed that baseline CRP did not predict for increased breast cancer risk. Similar data were reported in an analysis of the Women's Health Study [53]. Both these analyses were limited by single measurements of CRP which likely does not reflect long-term levels of inflammation. This limitation leads to uncertainty in the assessment of the association between inflammation and breast cancer risk.

These data have limitations. First, blood samples were collected from patients at only one time point. Therefore, these may not reflect levels of key mediators over time. Second, despite a large cohort population, the number of breast cancers was relatively small. This may have been influenced by our inclusion of only events occurring before unblinding of the study. Such case matching of a small subgroup of patients from a large randomized trial may be criticized. However, this was the only feasible methodology because after unblinding, patients on placebo were offered cross-over or enrolment on a randomized trial of tamoxifen versus raloxifene. It is hoped that the comprehensive background information and followup data derived from a randomized trial will negate these methodologic weaknesses. Third, due to matching by age, the differential effect of the tested blood levels in pre- and postmenopausal women could not be assessed robustly. Such analyses could also be confounded by pre-study use of hormone replacement therapy, although in our data, this variable did not appear to significantly affect breast cancer risk. Fourth, our choice of 25-hydroxy vitamin-D assay can be criticized. There can be substantial inter-assay differences in performance between different 25-hydroxy vitamin-D platforms [46], although these different methods have acceptable correlation [32]. Mass spectrometry-based assays likely results in the best calibration [46], but are not commonly used in clinical practice. Therefore, our use of electrochemiluminescence would likely have resulted in a balance between limited internal validity, but robust external validity. Finally, the population of women included in this study was at high risk for developing invasive breast cancer, and therefore may not be representative of all women. Despite these limitations, the meta-analysis shows that our findings are consistent with those from other studies where blood was collected before breast cancer diagnosis. These consistent findings which are not prone to reverse causation bias are likely to be a more accurate assessment of the association of vitamin-D metabolites and breast cancer risk.

In summary, when controlling for Gail score and adjusting for other factors independently associated with the risk of developing invasive breast cancer, suboptimal baseline levels of 25-hydroxy vitamin-D and increased 
baseline levels of insulin, CRP, and leptin levels do not show independent associations with the risk of breast cancer. BMI is a strong predictor of breast cancer, but the mechanisms underlying this association remain unclear. Further prospective data are required to further define how obesity influences breast cancer risk.

Acknowledgments The authors acknowledge funding support from Canadian Cancer Research Initiative (Grant \#019898), Public Health Service grants (U10-CA-37377 and U10-CA-69974) from the National Cancer Institute, and the Department of Health and Human Services.

Conflicts of interest All authors declare they have no relevant financial conflicts of interest.

\section{Reference}

1. Abbas S, Chang-Claude J, Linseisen J (2009) Plasma 25-hydroxyvitamin D and premenopausal breast cancer risk in a German case-control study. Int J Cancer 124:250-255

2. Abbas S, Linseisen J, Slanger T, Kropp S, Mutschelknauss EJ, Flesch-Janys D, Chang-Claude J (2008) Serum 25-hydroxyvitamin D and risk of post-menopausal breast cancer-results of a large case-control study. Carcinogenesis 29:93-99

3. Almquist $\mathrm{M}$, Bondeson AG, Bondeson L, Malm J, Manjer $\mathrm{J}$ (2010) Serum levels of vitamin D, PTH and calcium and breast cancer risk-a prospective nested case-control study. Int J Cancer 127:2159-2168

4. Amir E, Freedman OC, Seruga B, Evans DG (2010) Assessing women at high risk of breast cancer: a review of risk assessment models. J Natl Cancer Inst 102:680-691

5. Bertone-Johnson ER, Chen WY, Holick MF, Hollis BW, Colditz GA, Willett WC, Hankinson SE (2005) Plasma 25-hydroxyvitamin D and 1,25-dihydroxyvitamin D and risk of breast cancer. Cancer Epidemiol Biomark Prev 14:1991-1997

6. Burnand B, Kernan WN, Feinstein AR (1990) Indexes and boundaries for "quantitative significance" in statistical decisions. J Clin Epidemiol 43:1273-1284

7. Chen P, Hu P, Xie D, Qin Y, Wang F, Wang H (2010) Metaanalysis of vitamin $\mathrm{D}$, calcium and the prevention of breast cancer. Breast Cancer Res Treat 121:469-477

8. Chlebowski RT, Johnson KC, Kooperberg C, Pettinger M, Wactawski-Wende J, Rohan T, Rossouw J, Lane D, O'Sullivan MJ, Yasmeen S, Hiatt RA, Shikany JM, Vitolins M, Khandekar J, Hubbell FA (2008) Calcium plus vitamin D supplementation and the risk of breast cancer. J Natl. Cancer Inst 100:1581-1591

9. Chung M, Lee J, Terasawa T, Lau J, Trikalinos TA (2011) Vitamin D with or without calcium supplementation for prevention of cancer and fractures: an updated meta-analysis for the U.S. preventive services task force. Ann Intern Med 155:827-838

10. Cole SW (2009) Chronic inflammation and breast cancer recurrence. J Clin Oncol 27:3418-3419

11. Crew KD, Gammon MD, Steck SE, Hershman DL, Cremers S, Dworakowski E, Shane E, Terry MB, Desai M, Teitelbaum SL, Neugut AI, Santella RM (2009) Association between plasma 25-hydroxyvitamin D and breast cancer risk. Cancer Prev Res (Phila) 2:598-604

12. Cui Y, Rohan TE (2006) Vitamin D, calcium, and breast cancer risk: a review. Cancer Epidemiol Biomark Prev 15:1427-1437

13. Dawson-Hughes B, Heaney RP, Holick MF, Lips P, Meunier PJ, Vieth R (2005) Estimates of optimal vitamin D status. Osteoporos Int 16:713-716
14. Deeks JJ (2001) Systematic reviews in health care: systematic reviews of evaluations of diagnostic and screening tests. BMJ 323:157-162

15. DerSimonian R, Laird N (1986) Meta-analysis in clinical trials. Control Clin Trials 7:177-188

16. Eliassen AH, Spiegelman D, Hollis BW, Horst RL, Willett WC, Hankinson SE (2011) Plasma 25-hydroxyvitamin D and risk of breast cancer in the Nurses' Health Study II. Breast Cancer Res 13:R50

17. Engel P, Fagherazzi G, Boutten A, Dupre T, Mesrine S, BoutronRuault MC, Clavel-Chapelon F (2010) Serum 25(OH) vitamin D and risk of breast cancer: a nested case-control study from the French E3 N cohort. Cancer Epidemiol Biomark Prev 19:2341-2350

18. Fischer D, Becker S, Cordes T, Bucker B, Diedrich K, Friedrich M, Salehin D, Thill M (2009) Vitamin D-24-hydroxylase in benign and malignant breast tissue and cell lines. Anticancer Res 29:3641-3645

19. Fisher B, Costantino JP, Wickerham DL, Redmond CK, Kavanah M, Cronin WM, Vogel V, Robidoux A, Dimitrov N, Atkins J, Daly M, Wieand S, Tan-Chiu E, Ford L, Wolmark N (1998) Tamoxifen for prevention of breast cancer: report of the National Surgical Adjuvant Breast and Bowel Project P-1 Study. J Natl Cancer Inst 90:1371-1388

20. Forouhi NG, Luan J, Cooper A, Boucher BJ, Wareham NJ (2008) Baseline serum 25-hydroxy vitamin $d$ is predictive of future glycemic status and insulin resistance: the Medical Research Council Ely Prospective Study 1990-2000. Diabetes 57:2619-2625

21. Frati AC, Iniestra F, Ariza CR (1996) Acute effect of cigarette smoking on glucose tolerance and other cardiovascular risk factors. Diabetes Care 19:112-118

22. Freedman DM, Chang SC, Falk RT, Purdue MP, Huang WY, McCarty CA, Hollis BW, Graubard BI, Berg CD, Ziegler RG (2008) Serum levels of vitamin D metabolites and breast cancer risk in the prostate, lung, colorectal, and ovarian cancer screening trial. Cancer Epidemiol Biomark Prev 17:889-894

23. Garbin U, Fratta PA, Stranieri C, Cominacini M, Pasini A, Manfro S, Lugoboni F, Mozzini C, Guidi G, Faccini G, Cominacini L (2009) Cigarette smoking blocks the protective expression of Nrf2/ARE pathway in peripheral mononuclear cells of young heavy smokers favouring inflammation. PLoS One 4:e8225

24. Giovannucci E (2005) The epidemiology of vitamin D and cancer incidence and mortality: a review (United States). Cancer Causes Control 16:83-95

25. Goodwin PJ, Ennis M, Pritchard KI, Koo J, Hood N (2009) Prognostic effects of 25-hydroxyvitamin D levels in early breast cancer. J Clin Oncol 27:3757-3763

26. Hamajima N, Hirose K, Tajima K, Rohan T, Calle EE, Heath CW Jr, Coates RJ, Liff JM, Talamini R, Chantarakul N, Koetsawang S, Rachawat D, Morabia A, Schuman L, Stewart W, Szklo M, Bain C, Schofield F, Siskind V, Band P, Coldman AJ, Gallagher RP, Hislop TG, Yang P, Kolonel LM, Nomura AM, Hu J, Johnson KC, Mao Y, De SS, Lee N, Marchbanks P, Ory HW, Peterson HB, Wilson HG, Wingo PA, Ebeling K, Kunde D, Nishan P, Hopper JL, Colditz G, Gajalanski V, Martin N, Pardthaisong T, Silpisornkosol S, Theetranont C, Boosiri B, Chutivongse S, Jimakorn P, Virutamasen P, Wongsrichanalai C, Ewertz M, Adami HO, Bergkvist L, Magnusson C, Persson I, Chang-Claude J, Paul C, Skegg DC, Spears GF, Boyle P, Evstifeeva T, Daling JR, Hutchinson WB, Malone K, Noonan EA, Stanford JL, Thomas DB, Weiss NS, White E, Andrieu N, Bremond A, Clavel F, Gairard B, Lansac J, Piana L, Renaud R, Izquierdo A, Viladiu P, Cuevas HR, Ontiveros P, Palet A, Salazar SB, Aristizabel N, Cuadros A, Tryggvadottir L, Tulinius H, Bachelot A, Le MG, Peto J, Franceschi S, Lubin F, Modan B, Ron E, Wax Y, Friedman GD, Hiatt RA, Levi F, Bishop T, Kosmelj K, Primic-Zakelj M, Ravnihar B, Stare J, Beeson WL, 
Fraser G, Bullbrook RD, Cuzick J, Duffy SW, Fentiman IS, Hayward JL, Wang DY, McMichael AJ, McPherson K, Hanson RL, Leske MC, Mahoney MC, Nasca PC, Varma AO, Weinstein AL, Moller TR, Olsson H, Ranstam J, Goldbohm RA, van den Brandt PA, Apelo RA, Baens J, de la Cruz JR, Javier B, Lacaya LB, Ngelangel CA, La VC, Negri E, Marubini E, Ferraroni M, Gerber M, Richardson S, Segala C, Gatei D, Kenya P, Kungu A, Mati JG, Brinton LA, Hoover R, Schairer C, Spirtas R, Lee HP, Rookus MA, van Leeuwen FE, Schoenberg JA, McCredie M, Gammon MD, Clarke EA, Jones L, Neil A, Vessey M, Yeates D, Appleby P, Banks E, Beral V, Bull D, Crossley B, Goodill A, Green J, Hermon C, Key T, Langston N, Lewis C, Reeves G, Collins R, Doll R, Peto R, Mabuchi K, Preston D, Hannaford P, Kay C, Rosero-Bixby L, Gao YT, Jin F, Yuan JM, Wei HY, Yun T, Zhiheng C, Berry G, Cooper BJ, Jelihovsky T, MacLennan R, Shearman R, Wang QS, Baines CJ, Miller AB, Wall C, Lund E, Stalsberg H, Shu XO, Zheng W, Katsouyanni K, Trichopoulou A, Trichopoulos D, Dabancens A, Martinez L, Molina R, Salas O, Alexander FE, Anderson K, Folsom AR, Hulka BS, Bernstein L, Enger S, Haile RW, Paganini-Hill A, Pike MC, Ross RK, Ursin G, Yu MC, Longnecker MP, Newcomb P, Bergkvist L, Kalache A, Farley TM, Holck S, Meirik O (2002) Alcohol, tobacco and breast cancer-collaborative reanalysis of individual data from 53 epidemiological studies, including 58,515 women with breast cancer and 95,067 women without the disease. Br J Cancer 87:1234-1245

27. Harvie M, Hooper L, Howell AH (2003) Central obesity and breast cancer risk: a systematic review. Obes Rev 4:157-173

28. Holick MF (2006) Vitamin D: its role in cancer prevention and treatment. Prog. Biophys. Mol. Biol. 92:49-59

29. Holick MF (2007) Vitamin D deficiency. N Engl J Med 357:266-281

30. Housa D, Housova J, Vernerova Z, Haluzik M (2006) Adipocytokines and cancer. Physiol Res 55:233-244

31. Huang Z, Hankinson SE, Colditz GA, Stampfer MJ, Hunter DJ, Manson JE, Hennekens CH, Rosner B, Speizer FE, Willett WC (1997) Dual effects of weight and weight gain on breast cancer risk. JAMA 278:1407-1411

32. Jafri L, Khan AH, Siddiqui AA, Mushtaq S, Iqbal R, Ghani F, Siddiqui I (2011) Comparison of high performance liquid chromatography, radio immunoassay and electrochemiluminescence immunoassay for quantification of serum 25 hydroxy vitamin D. Clin Biochem 44:864-868

33. Lagunova Z, Porojnicu AC, Grant WB, Bruland O, Moan JE (2010) Obesity and increased risk of cancer: Does decrease of serum 25-hydroxyvitamin D level with increasing body mass index explain some of the association? Mol Nutr Food Res 54:1127-1133

34. Lowe LC, Guy M, Mansi JL, Peckitt C, Bliss J, Wilson RG, Colston KW (2005) Plasma 25-hydroxy vitamin D concentrations, vitamin D receptor genotype and breast cancer risk in a UK Caucasian population. Eur J Cancer 41:1164-1169

35. Madigan MP, Ziegler RG, Benichou J, Byrne C, Hoover RN (1995) Proportion of breast cancer cases in the United States explained by well-established risk factors. J Natl Cancer Inst 87:1681-1685

36. Maetani M, Maskarinec G, Franke AA, Cooney RV (2009) Association of leptin, 25-hydroxyvitamin D, and parathyroid hormone in women. Nutr Cancer 61:225-231

37. McCullough ML, Stevens VL, Patel R, Jacobs EJ, Bain EB, Horst RL, Gapstur SM, Thun MJ, Calle EE (2009) Serum 25-hydroxyvitamin D concentrations and postmenopausal breast cancer risk: a nested case control study in the Cancer Prevention StudyII Nutrition Cohort. Breast Cancer Res 11:R64

38. Muscogiuri G, Sorice GP, Prioletta A, Policola C, Della CS, Pontecorvi A, Giaccari A (2010) 25-Hydroxyvitamin D concentration correlates with insulin-sensitivity and BMI in obesity. Obesity (Silver Spring) 18:1906-1910

39. Pierce BL, Ballard-Barbash R, Bernstein L, Baumgartner RN, Neuhouser ML, Wener MH, Baumgartner KB, Gilliland FD, Sorensen BE, McTiernan A, Ulrich CM (2009) Elevated biomarkers of inflammation are associated with reduced survival among breast cancer patients. J Clin Oncol 27:3437-3444

40. Rejnmark L, Tietze A, Vestergaard P, Buhl L, Lehbrink M, Heickendorff L, Mosekilde L (2009) Reduced prediagnostic 25-hydroxyvitamin D levels in women with breast cancer: a nested case-control study. Cancer Epidemiol Biomark Prev 18:2655-2660

41. Rohan T (2007) Epidemiological studies of vitamin D and breast cancer. Nutr Rev 65:S80-S83

42. Rose DP, Vona-Davis L (2010) Interaction between menopausal status and obesity in affecting breast cancer risk. Maturitas 66:33-38

43. Ross AC, Manson JE, Abrams SA, Aloia JF, Brannon PM, Clinton SK, Durazo-Arvizu RA, Gallagher JC, Gallo RL, Jones G, Kovacs CS, Mayne ST, Rosen CJ, Shapses SA (2011) The 2011 report on dietary reference intakes for calcium and vitamin D from the Institute of Medicine: what clinicians need to know. J Clin Endocrinol Metab 96:53-58

44. Saad MF, Khan A, Sharma A, Michael R, Riad-Gabriel MG, Boyadjian R, Jinagouda SD, Steil GM, Kamdar V (1998) Physiological insulinemia acutely modulates plasma leptin. Diabetes 47:544-549

45. Segersten U, Holm PK, Bjorklund P, Hessman O, Nordgren $H$, Binderup L, Akerstrom G, Hellman P, Westin G (2005) 25-Hydroxyvitamin D3 1-alpha-hydroxylase expression in breast cancer and use of non-1-alpha-hydroxylated vitamin D analogue. Breast Cancer Res 7:R980-R986

46. Snellman G, Melhus H, Gedeborg R, Byberg L, Berglund L, Wernroth L, Michaelsson K (2010) Determining vitamin D status: a comparison between commercially available assays. PLoS One 5:e11555

47. Utriainen T, Malmstrom R, Makimattila S, Yki-Jarvinen H (1996) Supraphysiological hyperinsulinemia increases plasma leptin concentrations after $4 \mathrm{~h}$ in normal subjects. Diabetes 45:1364-1366

48. Veldhuis S, Wolbers F, Brouckaert O, Vermes I, Franke HR (2011) Cancer prevalence in osteoporotic women with low serum vitamin D levels. Menopause 18:319-322

49. Wortsman J, Matsuoka LY, Chen TC, Lu Z, Holick MF (2000) Decreased bioavailability of vitamin D in obesity. Am J Clin Nutr 72:690-693

50. Yan E, Chen S, Hong K, Kim WS, Bajpai A, Treyzon L, Gratton L, Elashoff R, Wang HJ, Li Z, Heber D (2008) Insulin, hs-CRP, leptin, and adiponectin. An analysis of their relationship to the metabolic syndrome in an obese population with an elevated waist circumference. Metab Syndr Relat Disord 6:64-73

51. Yao S, Sucheston LE, Millen AE, Johnson CS, Trump DL, Nesline MK, Davis W, Hong CC, McCann SE, Hwang H, Kulkarni S, Edge SB, O'Connor TL, Ambrosone CB (2011) Pretreatment serum concentrations of 25-hydroxyvitamin $\mathrm{d}$ and breast cancer prognostic characteristics: a case-control and a case-series study. PLoS One 6:17251-17252

52. Yin L, Grandi N, Raum E, Haug U, Arndt V, Brenner H (2010) Meta-analysis: serum vitamin $\mathrm{D}$ and breast cancer risk. Eur $\mathrm{J}$ Cancer 46:2196-2205

53. Zhang SM, Lin J, Cook NR, Lee IM, Manson JE, Buring JE, Ridker PM (2007) C-reactive protein and risk of breast cancer. J Natl Cancer Inst 99:890-894

54. Zittermann A, Frisch S, Berthold HK, Gotting C, Kuhn J, Kleesiek K, Stehle P, Koertke H, Koerfer R (2009) Vitamin D supplementation enhances the beneficial effects of weight loss on cardiovascular disease risk markers. Am J Clin Nutr 89:1321-1327 